\title{
Diffusing Capacity and Pulmonary Capillary Blood Flow at Hyperbaric Pressures *
}

\author{
Jean R. Nairn,† Gordon G. Power, $\ddagger$ R. W. Hyde, $\S$ R. E. Forster, \\ C. J. Lambertsen, and J. Dickson \\ (From the Department of Physiology, Graduate School of Medicine, and the Department of \\ Pharmacology, School of Medicine, University of Pennsylvania, Philadelphia, Pa.)
}

The pulmonary diffusing capacity $\left(\mathrm{DL}_{\mathrm{CO}}\right)$ has been observed to fall when the alveolar oxygen tension rises from 80 to $600 \mathrm{~mm} \mathrm{Hg}(1,2)$. By using the single breath technique in a hyperbaric pressure chamber, we have been able to extend the range of oxygen tensions studied up to 3,200 $\mathrm{mm} \mathrm{Hg}$.

Also we have measured in these experiments the effect of exposure of the pulmonary capillary bed to a partial pressure of oxygen of approximately $2,600 \mathrm{~mm} \mathrm{Hg}$ for a period of 10 minutes.

In addition, prompted by the suggestions of $\mathrm{J}$. S. Haldane (3), who postulated that inert molecules such as nitrogen may impede the mean free path of carbon monoxide molecules to the alveolar membrane and decrease the rate of uptake of carbon monoxide, we have studied the effect of large partial pressures of nitrogen on $\mathrm{DL}_{\mathbf{c o}}$.

\section{Methods}

In a hyperbaric chamber operating up to 4.8 atmospheres absolute pressure, a modification of the Krogh single breath technique (1) was used to measure the diffusing capacity for carbon monoxide (DLco). Simultaneously pulmonary capillary blood flow ( $\dot{Q} \mathrm{c})$ was measured by adding acetylene to the inspired mixture $(4,5)$. Neon instead of helium was used as the inert tracer gas (6). At sea level, the volume of the pulmonary parenchymal

* Submitted for publication March 26, 1965 ; accepted June 10, 1965.

This work was supported by a grant from the Life Insurance Medical Research Fund and by grant $\mathrm{He}$ 08184-01 from the National Institutes of Health.

† Isaac Ott Research Fellow and Fellow of the William McCann Research Trust.

$\ddagger$ Postdoctoral fellow of the National Institutes of Health.

$\S$ Daland Fellow of the American Philosophical Society.

Address requests for reprints to Dr. R. W. Hyde, Dept. of Physiology, University of Pennsylvania, Graduate Division of the School of Medicine, Philadelphia, $\mathrm{Pa}$. 19104. tissue in milliliters (Vr) was measured by plotting the acetylene disappearance with different times of breath holding in each subject (4).

The concentrations of neon, carbon monoxide, and acetylene were approximately constant in the inspired mixture, being $0.5 \%, 0.4 \%$, and $0.5 \%$, respectively, with a balance of oxygen and nitrogen. Four separate inspired mixtures were employed in which the oxygen concentrations were $6 \%, 21 \%, 60 \%$, and $98 \%$. By breathing different concentrations of oxygen for a few breaths followed by a breath of one of the inspired mixtures described, the alveolar oxygen tension of the subject during the breath holding period could be varied at will.

Neon, carbon monoxide, acetylene, and carbon dioxide concentrations were measured on a gas chromatograph (6) ${ }^{1}$ that has an error of $\pm 1 \%$. The oxygen concentration of the gases was measured on a mass spectrometer ${ }^{2}$ that has an accuracy of within $1 \%$. The residual volume in each subject was measured by the closed circuit helium technique (7). The pressure in the chamber in pounds per square inch was indicated on a calibrated Bourdon tube recording gauge outside the chamber that had a resolution of within $\frac{1}{2}$ pound per square inch $(50 \mathrm{~mm} \mathrm{Hg})$.

The plasma $\mathrm{CO}$ tension was estimated by having the subject rebreathe oxygen and hold his breath for 2 minutes and then measuring the carbon monoxide concentration in the expired sample $(2,8)$. This procedure was repeated at intervals throughout the experiment and the equilibrated capillary $\mathrm{CO}$ tension for each estimation of DLco calculated by interpolation to the prevailing oxygen tension. The apparatus used was similar to that previously described (5), mylar bags ${ }^{3}$ and copper and tygon tubing only being incorporated, as acetylene is absorbed by rubber.

The partial pressure of nitrogen $\left(\mathrm{P}_{2}\right)$ in the alveoli during the breath-holding period was estimated thus: $\mathrm{PN}_{2}=\mathrm{PB}_{\mathrm{B}}-\left(\mathrm{PH}_{2} \mathrm{O}+\mathrm{PO}_{2}+\mathrm{PCO}_{2}\right)$, where $\mathrm{PB}$ is the total barometric pressure, $\mathrm{PH}_{2} \mathrm{O}$ is the water vapor pressure

$1 \mathrm{We}$ found that the values of the neon/CO ratio drifted by $2 \%$ throughout the day of each experiment. We have therefore incorporated a correction factor to compensate for the drift on the basis of hourly sampling of the standard mixture. The neon $/ \mathrm{C}_{2} \mathrm{H}_{2}$ ratio remained constant throughout the day.

2 Model 21-620 A, Consolidated Engineering Co., Pasadena, Calif.

3 Supplied by Vac-Pac, Baltimore, Md. 
TABLE I

Physical characteristics of experimental subjects

\begin{tabular}{lccccc}
\hline \hline Subject & Sex & Age & Height & Weight & $\begin{array}{c}\text { Surface } \\
\text { area }\end{array}$ \\
\hline & & years & inches & pounds & $m^{2}$ \\
REF & M & 44 & 74 & 170 & 2.02 \\
RWH & M & 34 & 70 & 155 & 1.86 \\
GGP & M & 28 & 73 & 175 & 2.02 \\
GWK & M & 21 & 78 & 165 & 2.06 \\
JRN & F & 29 & 67 & 145 & 1.76 \\
\hline
\end{tabular}

at body temperature, and $\mathrm{Po}_{2}$ and $\mathrm{PCO}_{2}$ are partial pressures of oxygen and carbon dioxide, respectively, in alveolar gas.

The mean intracapillary oxygen tension at which the breath-holding maneuver was performed was calculated from the expired alveolar oxygen tension by assuming a diffusing capacity for oxygen of $20 \mathrm{ml} \mathrm{O}$ per ( $\mathrm{mm}$ $\mathrm{Hg} \times$ minutes) (9).

The alveolar oxygen tension present during the 5 to 10 minutes before the breath-holding procedure was calculated from the alveolar air equation (10). For convenience, this oxygen tension will be called hereafter the "preparatory level" to distinguish it from the mean in- tracapillary oxygen tension at which the breath-holding maneuver was performed.

The subjects studied included four males and one female who were symptomless and whose chests radiologically showed no active pulmonary disease or other abnormality. Their physical characteristics are shown in Table I. All were experienced in respiratory maneuvers.

The following experimental procedure was performed in each subject. At sea level, two control measurements, one at approximately $600 \mathrm{~mm} \mathrm{Hg}$ and another at approximately $120 \mathrm{~mm} \mathrm{Hg}$ mean intracapillary oxygen tension, were performed in the chamber with the doors open. The chamber was then sealed and the air compressed to 3.5 atmospheres absolute pressure. At least four breathholding maneuvers were performed at this pressure at mean intracapillary oxygen tensions from 200 to 2,400 $\mathrm{mm} \mathrm{Hg}$. Between each maneuver a gas mixture containing $6 \%$ oxygen in a balance of nitrogen was inspired for 5 to 8 minutes through a tight fitting mask so that at 3.5 atmospheres the preparatory level oxygen tension was approximately equal to that of breathing air at sea level $(110 \mathrm{~mm} \mathrm{Hg}$ ).

After these measurements at 3.5 atmospheres the subjects were divided into groups $\mathrm{A}$ and $\mathrm{B}$ and the procedure continued as follows. In each of two subjects ( $\mathrm{RWH}$ and GGP) in group A three further breath-hold-

TABLE II

Diffusing capacity $\left(D L_{C o}\right)$ and pulmonary capillary blood flow $(\dot{Q})$ in two subjects in group $A$

\begin{tabular}{|c|c|c|c|c|c|c|}
\hline Subject & Condition* & $\begin{array}{c}\text { "Preparatory } \\
\text { level" } \\
\text { alveolar oxygen } \\
\text { tension }\end{array}$ & $\begin{array}{c}\text { Mean } \\
\text { intracapil- } \\
\text { lary oxygen } \\
\text { tension }\end{array}$ & $\begin{array}{l}\text { PN2 in } \\
\text { alveoli }\end{array}$ & DLCo & $\dot{Q} c$ \\
\hline & & $m m \mathrm{Hg}$ & $m m \mathrm{Hg}$ & $m m \mathrm{Hg}$ & $\stackrel{m l C O /}{(\min \times m m} \mathrm{Hg})$ & $L / \min$ \\
\hline \multirow[t]{3}{*}{ RWH } & Sea level & $\begin{array}{l}106 \\
106\end{array}$ & $\begin{array}{l}578 \\
122\end{array}$ & $\begin{array}{r}97 \\
554\end{array}$ & $\begin{array}{l}19.1 \\
36.8\end{array}$ & $\begin{array}{l}9.6 \\
8.7\end{array}$ \\
\hline & $\begin{array}{l}3.5 \text { atmos- } \\
\text { pheres }\end{array}$ & $\begin{array}{r}116 \\
116 \\
116 \\
116 \\
2,579 \\
2,579 \\
2,579\end{array}$ & $\begin{array}{r}2,153 \\
1,885 \\
1,203 \\
227 \\
2,365 \\
1,625 \\
747\end{array}$ & $\begin{array}{r}439 \\
706 \\
1,389 \\
2,362 \\
223 \\
995 \\
1,849\end{array}$ & $\begin{array}{r}8.5 \\
9.2 \\
12.9 \\
35.3 \\
7.5 \\
9.0 \\
20.4\end{array}$ & $\begin{array}{l}9.0 \\
6.7 \\
8.0 \\
7.7 \\
7.8 \\
8.4 \\
7.7\end{array}$ \\
\hline & Sea level & $\begin{array}{l}106 \\
106\end{array}$ & $\begin{array}{l}585 \\
125\end{array}$ & $\begin{array}{r}88 \\
555\end{array}$ & $\begin{array}{l}17.8 \\
33.6\end{array}$ & $\begin{array}{l}9.2 \\
7.7\end{array}$ \\
\hline \multirow[t]{3}{*}{ GGP } & Sea level & $\begin{array}{l}106 \\
106\end{array}$ & $\begin{array}{l}576 \\
114\end{array}$ & $\begin{array}{r}89 \\
558\end{array}$ & $\begin{array}{l}20.1 \\
41.6\end{array}$ & $\begin{array}{r}10.0 \\
8.0\end{array}$ \\
\hline & $\begin{array}{l}3.5 \text { atmos- } \\
\text { pheres }\end{array}$ & $\begin{array}{r}117 \\
117 \\
117 \\
117 \\
2,593 \\
2,593 \\
2,593\end{array}$ & $\begin{array}{r}1,981 \\
1,963 \\
1,142 \\
154 \\
2,320 \\
1,611 \\
931\end{array}$ & $\begin{array}{r}597 \\
614 \\
1,436 \\
2,412 \\
254 \\
969 \\
1,651\end{array}$ & $\begin{array}{r}7.8 \\
8.7 \\
11.8 \\
39.7 \\
7.2 \\
8.6 \\
13.2\end{array}$ & $\begin{array}{l}8.4 \\
6.6 \\
5.7 \\
7.0 \\
4.3 \\
5.1 \\
5.8\end{array}$ \\
\hline & Séa level & $\begin{array}{l}106 \\
106\end{array}$ & $\begin{array}{l}593 \\
117\end{array}$ & $\begin{array}{r}74 \\
559\end{array}$ & $\begin{array}{l}17.4 \\
34.8\end{array}$ & $\begin{array}{l}7.5 \\
5.9\end{array}$ \\
\hline
\end{tabular}

* Measurements listed in order performed.

$+\mathrm{PN}_{2}=$ partial pressure of nitrogen. 
TABLE III

Diffusing capacity and pulmonary capillary blood flow in three subjects in group $B$

\begin{tabular}{|c|c|c|c|c|c|c|}
\hline - Subject & Condition* & $\begin{array}{l}\text { "Preparatory } \\
\text { level" } \\
\text { alveolar oxygen } \\
\text { tension }\end{array}$ & $\begin{array}{c}\text { Mean } \\
\text { intracapil- } \\
\text { lary oxygen } \\
\text { tension }\end{array}$ & $\begin{array}{l}\text { Nitrogen } \\
\text { tension in } \\
\text { alveoli }\end{array}$ & DlCo & $\dot{\mathrm{Q}} \mathrm{c}$ \\
\hline & & $m m \mathrm{Hg}$ & $m m \mathrm{Hg}$ & $m m \mathrm{Hg}$ & $\underset{(\min \times m m}{m l C O /} \mathrm{Hg})$ & $L / \min$ \\
\hline \multirow[t]{4}{*}{ REF } & Sea level & $\begin{array}{l}106 \\
106\end{array}$ & $\begin{array}{l}598 \\
116\end{array}$ & $\begin{array}{r}76 \\
560\end{array}$ & $\begin{array}{l}15.3 \\
28.4\end{array}$ & $\begin{array}{l}6.5 \\
5.0\end{array}$ \\
\hline & $\begin{array}{l}4.8 \text { atmos- } \\
\text { pheres }\end{array}$ & $\begin{array}{l}180 \\
180\end{array}$ & $\begin{array}{l}3,095 \\
3,115\end{array}$ & $\begin{array}{l}483 \\
465\end{array}$ & $\begin{array}{l}5.4 \\
5.8\end{array}$ & $\begin{array}{l}4.3 \\
4.4\end{array}$ \\
\hline & $\begin{array}{c}3.5 \text { atmos- } \\
\text { pheres }\end{array}$ & $\begin{array}{l}117 \\
117 \\
117 \\
117 \\
117\end{array}$ & $\begin{array}{r}2,257 \\
1,807 \\
1,705 \\
1,103 \\
243\end{array}$ & $\begin{array}{r}332 \\
788 \\
889 \\
1,491 \\
2,335\end{array}$ & $\begin{array}{r}6.9 \\
8.0 \\
7.4 \\
9.5 \\
20.8\end{array}$ & $\begin{array}{l}4.4 \\
3.3 \\
4.2 \\
3.6 \\
5.3\end{array}$ \\
\hline & Sea level & $\begin{array}{l}106 \\
106\end{array}$ & $\begin{array}{l}590 \\
117\end{array}$ & $\begin{array}{r}84 \\
559\end{array}$ & $\begin{array}{l}12.8 \\
26.7\end{array}$ & $\begin{array}{l}5.4 \\
6.6\end{array}$ \\
\hline \multirow[t]{4}{*}{$\mathrm{JRN}$} & Sea level & $\begin{array}{l}106 \\
106\end{array}$ & $\begin{array}{l}607 \\
139\end{array}$ & $\begin{array}{r}78 \\
548\end{array}$ & $\begin{array}{r}9.7 \\
18.5\end{array}$ & $\begin{array}{l}7.3 \\
5.5\end{array}$ \\
\hline & $\begin{array}{c}3.5 \text { atmos- } \\
\text { pheres }\end{array}$ & $\begin{array}{l}117 \\
117 \\
117 \\
117 \\
117\end{array}$ & $\begin{array}{r}2,175 \\
1,865 \\
1,555 \\
1,215 \\
284\end{array}$ & $\begin{array}{r}419 \\
730 \\
1,054 \\
1,383 \\
2,311\end{array}$ & $\begin{array}{r}3.5 \\
3.9 \\
4.5 \\
6.1 \\
14.1\end{array}$ & $\begin{array}{l}5.3 \\
4.8 \\
4.5 \\
4.6 \\
4.2\end{array}$ \\
\hline & $\begin{array}{l}4.8 \text { atmos- } \\
\text { pheres }\end{array}$ & $\begin{array}{l}180 \\
180\end{array}$ & $\begin{array}{l}3,195 \\
3,065\end{array}$ & $\begin{array}{l}396 \\
526\end{array}$ & $\begin{array}{l}2.0 \\
1.8\end{array}$ & $\begin{array}{l}4.4 \\
4.8\end{array}$ \\
\hline & Sea level & $\begin{array}{l}106 \\
106\end{array}$ & $\begin{array}{l}654 \\
120\end{array}$ & $\begin{array}{r}31 \\
558\end{array}$ & $\begin{array}{r}9.0 \\
16.7\end{array}$ & $\begin{array}{l}6.0 \\
4.4\end{array}$ \\
\hline \multirow[t]{4}{*}{ GWK } & Sea level & $\begin{array}{l}106 \\
106\end{array}$ & $\begin{array}{l}572 \\
108\end{array}$ & $\begin{array}{r}76 \\
566\end{array}$ & $\begin{array}{l}19.8 \\
41.3\end{array}$ & $\begin{array}{l}7.8 \\
9.9\end{array}$ \\
\hline & $\begin{array}{l}3.5 \text { atmos- } \\
\text { pheres }\end{array}$ & $\begin{array}{l}117 \\
117 \\
117 \\
117 \\
117\end{array}$ & $\begin{array}{r}2,205 \\
1,850 \\
1,545 \\
1,230 \\
182\end{array}$ & $\begin{array}{r}392 \\
746 \\
1,051 \\
1,378 \\
2,414\end{array}$ & $\begin{array}{r}6.8 \\
8.1 \\
9.1 \\
9.8 \\
18.1\end{array}$ & $\begin{array}{l}5.5 \\
6.6 \\
5.3 \\
3.9 \\
4.8\end{array}$ \\
\hline & $\begin{array}{l}4.8 \text { atmos- } \\
\text { pheres }\end{array}$ & $\begin{array}{l}180 \\
180\end{array}$ & $\begin{array}{l}2,965 \\
2,915\end{array}$ & $\begin{array}{l}620 \\
671\end{array}$ & $\begin{array}{l}5.1 \\
4.8\end{array}$ & $\begin{array}{l}5.3 \\
5.5\end{array}$ \\
\hline & Sea level & $\begin{array}{l}106 \\
106\end{array}$ & $\begin{array}{l}593 \\
113\end{array}$ & $\begin{array}{r}88 \\
567\end{array}$ & $\begin{array}{l}16.0 \\
28.5\end{array}$ & $\begin{array}{l}5.9 \\
5.9\end{array}$ \\
\hline
\end{tabular}

* Measurements listed in the order performed.

ing maneuvers were performed at 3.5 atmospheres, varying the mean intracapillary oxygen tension at the time of breath holding from 600 to $2,400 \mathrm{~mm} \mathrm{Hg}$. However, approximately $100 \%$ oxygen was administered through a mouthpiece for a preliminary 10 minutes before each run, maintaining a preparatory level oxygen tension of approximately $2,600 \mathrm{~mm} \mathrm{Hg}$ for this time, and not 110 $\mathrm{mm} \mathrm{Hg}$ as in the experiments above.

With three subjects (REF, JRN, and GWK) in group $B$, the pressure was increased to 4.8 atmospheres, where duplicate measurements were made at a mean intracapil- lary oxygen tension of $3,000 \mathrm{~mm} \mathrm{Hg}$. Between measurements a mixture of $6 \%$ oxygen in nitrogen was inspired through a mask for 5 to 8 minutes.

Graduated decompression took between 3 and 4 hours during which time the subject was reclining and intermittently sleeping in an easy chair. The final controls were performed on return to sea level.

Estimations of plasma $\mathrm{CO}$ tension as described above were made between every second breath-holding maneuver. At each barometric pressure the highest oxygen tension runs were performed first. 




Fig. 1. EFfect OF MEAN INTRACapillary OXYGEN TENSION ON PULMONARY DIFFUSING CAPACITY (DLCo) IN FIVE SUBJECTS. The lines show the trend in each subject.

\section{Results}

The results are shown in Tables II and III. The pulmonary diffusing capacity $\left(\mathrm{D}_{\mathrm{L}} \mathrm{C}\right)$ in milliliters $\mathrm{CO}$ per (minute $\times$ millimeters $\mathrm{Hg}$ ) decreased in all subjects with rising mean intracapillary oxygen tension (Figure 1 ). In the three subjects in group B (JRN, REF, and GWK) where duplicate measurements were made at 4.8 atmospheres and the mean intracapillary oxygen tension was between $2,900 \mathrm{~mm} \mathrm{Hg}$ and $3,200 \mathrm{~mm} \mathrm{Hg}$, the

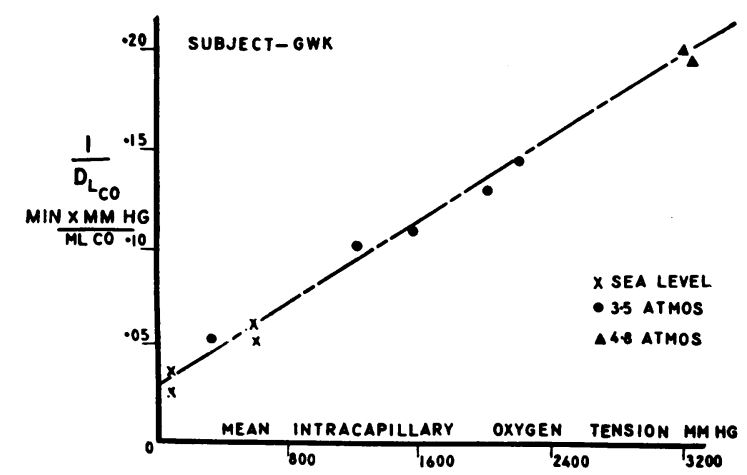

Fig. 2. The relationship between Dlco and mean INTRACAPILLARY OXYGEN TENSION AT SEA LEVEL AND AT 3.5 AND 4.8 ATMOSPHERES PRESSURE IN SUBJECT GWK. The straight line is the regression based on all the points. $r=.992$. diffusing capacity was reduced on the average to $15 \%$ of the value measured at normal alveolar oxygen tension (approximately $110 \mathrm{~mm} \mathrm{Hg}$ ).

$1 / \mathrm{DL}_{\mathrm{CO}}$ increased approximately in a linear relation with the mean intracapillary oxygen tension (see Figure 2). The average correlation coefficient between $1 / \mathrm{DL}_{\mathrm{CO}}$ and mean intracapillary oxygen tension in the five subjects was 0.986 .

Figure 3 shows $1 / \mathrm{DL}_{\text {Co }}$ measured after a preceding preparatory level of $116 \mathrm{~mm}$ alveolar oxygen tension and again after a preparatory level of approximately $2,580 \mathrm{~mm}$ oxygen tension in one subject $(\mathrm{RWH})$. The mean intracapillary oxygen tension at which $\mathrm{DL}_{\mathrm{co}}$ was measured is shown on the abscissa. The straight, dashed line is the re-

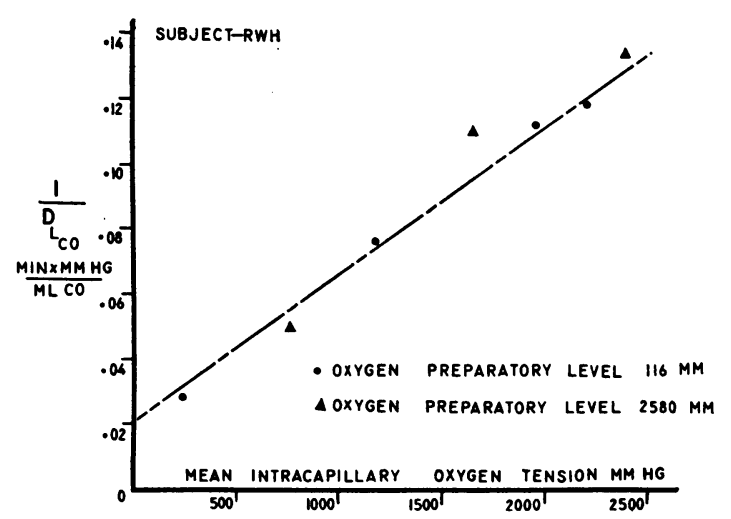

Fig. 3. ThE efFect OF DIFFERENT PREPARATORY LEVELS of OXYGEN on DLco. The straight line is the regression based on the lower preparatory level points. The higher preparatory level points lie within $2 \mathrm{SE}$ of this line.

gression line based on the measurements made after a preparatory level at the lower oxygen tension. The higher preparatory level points lie within $2 \mathrm{SE}$ of this line. In the other subject who performed these maneuvers (GGP), there was also no consistent difference observed between the values of $\mathrm{DL}_{\mathrm{Co}}$ measured after different preparatory levels of $\mathrm{O}_{2}$ tension.

The partial pressure of nitrogen $\left(\mathrm{PN}_{2}\right)$ present at the time of breath holding varied from $30 \mathrm{~mm}$ to $2,400 \mathrm{~mm} \mathrm{Hg}$. Figure 4 shows the values of $1 / \mathrm{DL}_{\mathrm{CO}}$ plotted against the mean intracapillary oxygen tension with the $\mathrm{PN}_{2}$ values indicated as numbers. The presence of large partial pressures of nitrogen did not affect the value of $1 / \mathrm{DL}_{\mathrm{CO}}$ in a consistent fashion in any of the subjects studied.

The control values of $\mathrm{DL}_{\mathrm{Co}}$ after the whole procedure consistently fell in all five subjects in com- 


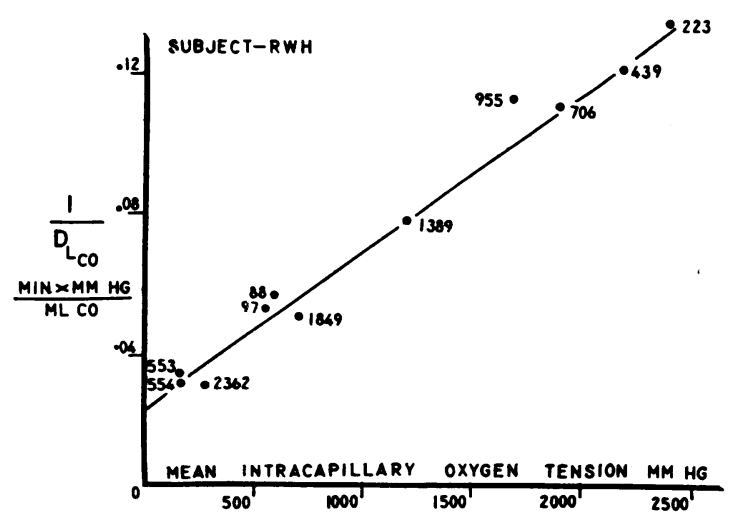

Fig. 4. EFFECT OF INDEPENDENT VARIATION OF THE PARTIAL PRESSURE OF NITROgen $\left(\mathrm{P}_{\mathrm{N}_{2}}\right)$ on Dlco. The figures beside the points are values of $\mathrm{PN}_{2}$ present at the time of breath holding in millimeters $\mathrm{Hg}$. The straight line is a regression line relating $D_{\text {Lco }}$ and the intracapillary oxygen tension.

parison with those measured before. The average fall from the initial value was $14.4 \%$ with normal alveolar oxygen tensions $(120 \mathrm{~mm} \mathrm{Hg})$ and $13.0 \%$ with oxygen tensions of approximately $570 \mathrm{~mm}$ $\mathrm{Hg}$.

The pulmonary capillary blood flow (这) fell from the mean value of $7.9 \mathrm{~L}$ per minute at sea level to $5.8 \mathrm{~L}$ per minute at 3.5 atmospheres, which represents a $27 \%$ drop from the initial value. In two subjects (RWH and REF) Qc returned after the whole procedure to the original sea level value. The final average control value of $\dot{Q} c$ in the other three subjects (GWK, JRN, and GGP) was $66 \%$, $82 \%$, and $75 \%$, respectively, of their initial sea level control.

Of the two subjects in group $A$, the average $\dot{Q} c$ of subject GGP dropped from 7.0 L per minute to $5.1 \mathrm{~L}$ per minute after approximately $100 \%$ oxygen had been inspired for 10 minutes at 3.5 atmospheres, but Qc increased slightly in RWH (Figure 5). There was no obvious difference in Qc measured at 3.5 atmospheres and 4.8 atmospheres in the three subjects in group B. No correlation was seen between $\dot{Q} c$ and the mean intracapillary oxygen tension during breath holding.

\section{Discussion}

These experiments showed that the diffusing capacity for carbon monoxide decreases progressively with rising oxygen tension from 100 to $3,200 \mathrm{~mm} \mathrm{Hg}$. The mechanism for this decrease is thought to be as follows. The rate of removal of carbon monoxide from the alveolar gas is limited, in part, by the rate of formation of carboxyhemoglobin in the red cell which, in turn, is proportional to the concentration of unsaturated hemoglobin molecules present. As a consequence of the rising $\mathrm{Po}_{2}$ in the red cell, fewer unsaturated hemoglobin molecules are available for the formation of carboxyhemoglobin. These data show that even in the presence of a mean intracapillary oxygen tension of approximately $3,000 \mathrm{~mm} \mathrm{Hg}$, there is a measurable diffusing capacity for carbon monoxide, which can only mean there is still unsaturated hemoglobin present. This is not so surprising when it is considered that although there may be only a minute amount of unsaturated hemoglobin present at any instant, it is the net result of extremely rapid association with and dissociation from oxygen.

In the above experiments oxygen may have altered the actual properties of the pulmonary mem-

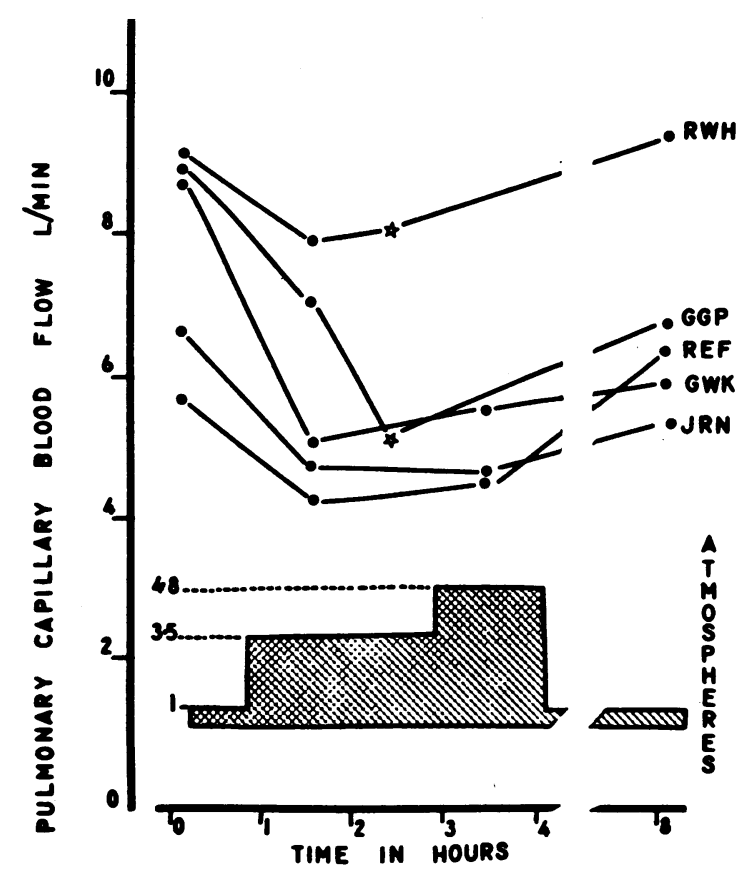

Fig. 5. EFFECT OF DIFFERENT BAROMETRIC PRESSURE ON THE AVERAGE VALUES OF CAPILLARY BLOOD FLOW IN FIVE SUBJECTS. The dots are measurements made after a preparatory level of approximately $110 \mathrm{~mm} \mathrm{O}_{2}$ tension, and the stars after a preparatory level of $2,580 \mathrm{~mm} \mathrm{O}_{2}$ tension. The abscissa is only an approximate time schedule and applies in all subjects with the exception of $\mathrm{REF}$, where measurements at 4.8 atmospheres were performed before those at 3.5 atmospheres. 
TABLE IV

Calculated values of Vc and DM above and below mean intracapillary oxygen tensions of $600 \mathrm{~mm} \mathrm{Hg}$

\begin{tabular}{|c|c|c|c|c|}
\hline \multirow[b]{2}{*}{ Subject } & \multicolumn{2}{|c|}{$\mathrm{Vc}$} & \multicolumn{2}{|c|}{ DM } \\
\hline & $\begin{array}{c}\text { Alveolar } \\
\mathrm{PO}_{2} \\
<600 \\
\mathrm{~mm} \mathrm{Hg} \dagger\end{array}$ & $\begin{array}{c}\text { Alveolar } \\
\text { PO2 }^{>600} \\
\text { mm Hg } \ddagger\end{array}$ & $\begin{array}{c}\text { Alveolar } \\
\text { PO2 }^{2} \\
<600 \\
\text { mm Hg† }\end{array}$ & $\begin{array}{c}\text { Alveolar } \\
\text { PO2 }^{2} \\
>600 \\
\text { mm Hgt }\end{array}$ \\
\hline & \multicolumn{2}{|c|}{$m l$} & \multicolumn{2}{|c|}{$\underset{\times \mathrm{ml}}{\mathrm{Cl} / \mathrm{Hg})}$} \\
\hline RWH & 112 & 119 & 57 & 91 \\
\hline GWK & 103 & 98 & 67 & 77 \\
\hline REF & 80 & 208 & 53 & 12 \\
\hline GGP & 106 & 125 & 72 & 77 \\
\hline JRN & 56 & 40 & 33 & 435 \\
\hline
\end{tabular}

$* \mathrm{Vc}=$ blood volume in the pulmonary capillaries; $\mathrm{DM}=$ diffusing capacity of the membrane.

$t$ Using measured $\theta$ relationship to oxygen tension.

$\mp$ Using assumed $\theta$ relationship to oxygen tension. $\theta$ has been meas ured only at $\mathrm{O}_{2}$ tensions less than $600 \mathrm{~mm} \mathrm{Hg}$, and values for highe oxygen tensions had to be obtained by extrapolation from the known data.

brane and vascular bed thereby affecting the diffusing capacity, $\mathrm{DL}_{\mathrm{Co}}$. But, as previously pointed out (11), this seems unlikely since changes in the membrane and vascular bed would have to occur within the several seconds required for the measurement of $\mathrm{DL}_{\mathrm{CO}}$ by the single breath technique. In the preparatory level experiments we tested for possible changes in the pulmonary diffusing surface by having subjects breathe oxygen for 10 minutes at an alveolar oxygen tension of approximately $2,600 \mathrm{~mm} \mathrm{Hg}$. We attempted to separate possible effects on the pulmonary diffusing surface from changes in $D_{L_{C O}}$ resulting from altered reaction kinetics within the red cell, which are influenced by the oxygen tension at the particular moment, by quickly (within 5 to 8 seconds) changing the alveolar oxygen tension and then measuring $\mathrm{DL}_{\mathrm{CO}}$. We found that $\mathrm{DL}_{\mathrm{Co}}$ was affected only by the oxygen tension in the alveoli at the time of breath holding and not by the preparatory level and have concluded, therefore, that the diffusing surface and gas exchange vessels are not affected by breathing oxygen for 10 minutes with an alveolar partial pressure of approximately $2,600 \mathrm{~mm}$ $\mathrm{Hg}$. Other investigators have reported pulmonary edema in animals (12) and a lowering of $D_{L_{C O}}$ in human subjects (13) who breathed oxygen for longer periods at sea level, changes that infer injury to the pulmonary membrane and vascular bed. Possibly in our experiments a longer exposure to oxygen would have produced a decrease in diffusing capacity, but we voluntarily restricted our experiments to 10 minutes of oxy- gen breathing at 3.5 atmospheres in order to reduce the likelihood of oxygen toxicity and seizures.

The concept of large numbers of nitrogen molecules impeding the diffusion of carbon monoxide molecules in the gas phase and thereby producing gradients within the alveolar air has been discussed previously (11). On theoretical grounds the nitrogen pressures in our experiments were not high enough to have impaired diffusion significantly. However, if this were an important facet and had affected the rate of gas diffusion within the alveolar air, a decrease in $\mathrm{DL}_{\mathrm{CO}}$ would have been found at increased atmospheric pressure when there were more nitrogen molecules present. In our experiments a variation of nitrogen partial pressures from 30 to $2,400 \mathrm{~mm}$ apparently did not affect $\mathrm{DL}_{\mathrm{co}}$, results which support the theory that diffusion within the alveolar gas itself is not a significant limitation to the passage of gas into the blood.

In these experiments a nearly linear relationship has been shown to exist between $1 / \mathrm{DL}_{\mathrm{Co}}$ and the mean intracapillary oxygen tension at the time of breath holding in all subjects. We have applied the equation (14),

$$
1 / \mathrm{DL}_{\mathrm{CO}}=(1 / \mathrm{DM})+(1 / \theta \mathrm{Vc}),
$$

to calculate the value of $\mathrm{DM}$, the diffusing capacity of the membrane in milliliters $\mathrm{CO}$ per (minute $X$ millimeters $\mathrm{Hg}$ ), and $\mathrm{Vc}$, the volume of the blood in milliliters in the pulmonary capillaries in all subjects using the measured values for $\theta$ (14), the rate at which the red cells in $1.0 \mathrm{ml}$ of pulmonary capillary blood will absorb $\mathrm{CO}$ in milliliters per minute per millimeter $\mathrm{Hg}$ plasma $\mathrm{CO}$ tension. If the ratio of permeability of the red cell membrane to that of the red cell interior is assumed to be $2.5, \theta$ is related to the intracorpuscular oxygen tension as follows (5):

$$
1 / \theta=0.73+4.4 \mathrm{Po}_{2},
$$

where $\mathrm{Po}_{2}$ is the intracorpuscular oxygen tension in atmospheres.

Equation 2 has been used to calculate the value of $1 / \theta$ from the measured mean intracapillary oxygen tension in all our experiments, and with this value, $\mathrm{Dm}$ and $\mathrm{Vc}$ have been calculated from Equation 1. As Equation 2 is based on measurements of oxygen tensions only up to $600 \mathrm{~mm}$ $\mathrm{Hg}$, the calculated values of $\mathrm{DM}_{\mathrm{M}}$ and $\mathrm{Vc}$ from 
oxygen tensions above $600 \mathrm{~mm} \mathrm{Hg}$ have been kept separate from those measured at sea level (i.e., at oxygen tensions below $600 \mathrm{~mm} \mathrm{Hg}$ ). The results of these calculated values are shown in Table IV. When Vc calculated from values of $\theta$ obtained by extrapolation to higher oxygen tensions are compared with $\mathrm{Vc}$ calculated from experimental values of $\theta$ at oxygen tensions below $600 \mathrm{~mm} \mathrm{Hg}$, four of five subjects show similar results. Three of the five subjects also have comparable $D_{M}$ values. If the error of the method incurred at very high oxygen tensions, as explained in detail below, is taken into account, these results probably mean that $1 / \theta$ bears the same relationship to the mean intracapillary oxygen tension up to $3,000 \mathrm{~mm} \mathrm{Hg}$ as defined up to $600 \mathrm{~mm} \mathrm{Hg}$ tension by Equation 2 .

In the measurement of DLCO at high oxygen partial pressures, the ratio of the initial alveolar $\mathrm{CO}$ concentration to the final alveolar $\mathrm{CO}$ concentration $\left(\mathrm{F}_{\mathrm{ACO}_{0}} / \mathrm{F}_{\mathrm{ACO}_{t}}\right)$ approaches unity, and in this event any error is greatly magnified. The equilibrated plasma $\mathrm{CO}$ tension becomes critical as well. For example, if a subject has a $D_{L_{C O}}$ of $30 \mathrm{ml}$ of $\mathrm{CO}$ per (minute $\times$ millimeters $\mathrm{Hg}$ ), an alveolar volume of $5,000 \mathrm{ml}$ standard temperature and pressure, dry, and a breath-holding time of 10 seconds, a $5 \%$ error in the measured expired alveolar concentration of carbon monoxide will introduce a $7 \%$ error in the calculated $\mathrm{DL}_{\mathrm{co}}$. However, if the $\mathrm{DL}_{\mathrm{CO}}$ is $5 \mathrm{ml}$ of $\mathrm{CO}$ per (minute $\times$ millimeters $\mathrm{Hg}$ ) with the same alveolar volume and breathholding time, a 5\% error in the measurement of the expired alveolar concentration will be magnified to a $32 \%$ error in the calculated $\mathrm{DL}_{\mathrm{CO}}$. This magnification of errors at high oxygen tension may explain, in part, the wide variation in some of the measurements of $\mathrm{DM}$ and Vc at oxygen tensions over $600 \mathrm{~mm} \mathrm{Hg}$ (see Table IV).

The average control $\mathrm{DL}_{\mathrm{Co}}$ decreased $14 \%$ in all subjects after the day's experiment in the chamber when compared to initial control values. To elucidate the matter further, two subjects, GGP and GWK, who had previously shown an average fall in $\mathrm{DL}_{\mathrm{CO}}$ of $15 \%$ and $25 \%$, respectively, were tested again. The subjects were seated in the chamber in easy chairs, but were not exposed to hyperbaric pressures or given any supplemental oxygen. Five measurements of $\mathrm{DL}_{\mathrm{co}}$ and $\mathrm{Qc}$ were made in each subject at 5-minute intervals in the morning and another five in the afternoon ap- proximately 4 to 5 hours later. The results are shown in Table $\mathrm{V}$, and we see that $\mathrm{DL}_{\mathrm{co}}$ dropped in much the same way as in the original experiments; the significance levels are shown. Since these subjects breathed only room air at sea level, this fall in DLco cannot be due to oxygen inhalation or to increased barometric pressure per se, but rather seems related to the subjects' prolonged inactivity, (15) and to changes in $\dot{Q} c$ (5). This is an interesting finding that will require further investigation.

We are aware of reports that during oxygen breathing at 2.0 to 3.5 atmospheres, normal men showed an unexplained alveolar-arterial oxygen tension difference indirectly measured to be as high as $100 \mathrm{~mm} \mathrm{Hg}$ at 2.0 atmospheres (16), 400 $\mathrm{mm} \mathrm{Hg}$ at 3.0 atmospheres (17), and $550 \mathrm{~mm}$ $\mathrm{Hg}$ at 3.5 atmospheres (18). On the other hand, no large alveolar-arterial oxygen tension difference was found by Rennie and Pappenheimer (19) in dogs breathing oxygen at 2 atmospheres ambient pressure. In recent applications of the oxygen electrode to the measurement of arterial $\mathrm{Po}_{2}$ in hyperoxygenated subjects, large alveolar-arterial gradients were again reported (20). This possible increase in the alveolar-arterial oxygen gradient does not necessarily relate to the depression of $\mathrm{DL}_{\mathrm{Co}}$ by oxygen observed in the present study. Even though the uptake of oxygen in the lungs normally appears to be partially limited by the rate at which oxygen can react with intracellular, unsaturated hemoglobin (21), this does not in any way imply that complete equilibration between alveolar and capillary oxygen tension would not be expected theoretically at the end of the capillary no matter how great the absolute alveolar oxygen tension. For example, the mixed venous blood entering the pulmonary capillary bed would have a relatively low $\mathrm{Po}_{2}$ and therefore a normal $\mathrm{DL}_{\mathrm{O}_{2}}$, leading to nearly complete saturation of all the hemoglobin before the blood $\mathrm{Po}_{2}$ could rise over $150 \mathrm{~mm} \mathrm{Hg}$. Once the hemoglobin is fully saturated, further increase in oxygen content in the blood is only in the form of physically dissolved gas, and the only limitation to further transfer is the diffusing capacity of the pulmonary membrane (22). In these circumstances, the reaction rate for oxygen with hemoglobin is of no further concern. For reasons previously given the pulmonary membrane does not appear to be affected by short 
TABLE V

$D L_{C o}$ and $\dot{Q} c$ before and after a 4- to 5-hour period sitting at sea level

\begin{tabular}{|c|c|c|c|c|c|c|}
\hline \multirow[b]{2}{*}{ Subject } & \multicolumn{2}{|c|}{ Dico } & \multicolumn{2}{|c|}{$\dot{Q} \mathrm{c}$} & \multicolumn{2}{|c|}{$\begin{array}{c}\text { Mean intracapillary } \\
\text { oxygen tension }\end{array}$} \\
\hline & Before & After & Before & After & Before & After \\
\hline & \multicolumn{2}{|c|}{$m l \mathrm{CO} /(\min \times m m \mathrm{Hg})$} & \multicolumn{2}{|c|}{$L / \min$} & \multicolumn{2}{|c|}{$m m \mathrm{Hg}$} \\
\hline \multirow[t]{2}{*}{ GGP } & $39.9 \pm 6.7$ & $35.7 \pm 3.0$ & $7.0 \pm 0.6$ & $6.4 \pm 0.7$ & 118 & 121 \\
\hline & \multicolumn{2}{|c|}{$\mathrm{p}<0.05$} & \multicolumn{2}{|c|}{$\mathrm{NS}$ at 0.5 level } & & \\
\hline \multirow[t]{2}{*}{ GWK } & $34.1 \pm 3.0$ & $31.7 \pm 2.6$ & $4.5 \pm 0.4$ & $5.2 \pm 1.0$ & 112 & 117 \\
\hline & \multicolumn{2}{|c|}{$\mathrm{p}<0.1$} & \multicolumn{2}{|c|}{ NS at 0.1 level } & & \\
\hline
\end{tabular}

periods of high $\mathrm{Po}_{2}$, and, at an alveolar $\mathrm{Po}_{2}$ of $2,000 \mathrm{~mm} \mathrm{Hg}$, equilibration of physically dissolved oxygen can be calculated to be $99 \%$ complete in less than 0.03 second, assuming a pulmonary capillary blood volume of $100 \mathrm{ml}$ and a diffusing capacity for oxygen of the pulmonary membrane of $40 \mathrm{ml}$ per minute per $\mathrm{mm} \mathrm{Hg}(23,24)$.

The fact that the plot of $1 / \mathrm{DL}_{\mathrm{Co}}$ against $\mathrm{Po}_{2}$ (Figure 4) remains linear at the extremely high alveolar oxygen tensions implies that the mean capillary $\mathrm{PO}_{2}$ continues to rise linearly as alveolar $\mathrm{Po}_{2}$ rises.

Thus, since neither diffusion limitation, gross shunting of blood across the lungs, nor other mechanisms to interfere with the movement of oxygen have been identified as a consequence of short periods of oxygen breathing at high pressures, the authors are not now prepared to explain the apparent gross interference with oxygen uptake.

\section{Summary}

The pulmonary diffusing capacity $\left(\mathrm{DL}_{\mathrm{co}}\right)$ and capillary blood flow (Qc) were calculated from the disappearance of low concentrations of carbon monoxide and acetylene from the alveolar gas during breath holding. Such measurements were performed in five normal subjects in a hyperbaric pressure chamber at sea level and at 3.5 and 4.8 atmospheres absolute.

DLco was found to decrease progressively with rising oxygen tension. $1 / \mathrm{DL}_{\mathrm{Co}}$ increased linearly with rising mean intracapillary oxygen tension from 110 to $3,200 \mathrm{~mm} \mathrm{Hg}$ (average $r=0.986$ ). $\mathrm{DL}_{\text {Co }}$ was not changed significantly by independent variation of nitrogen partial pressure from 30 to $2,400 \mathrm{~mm} \mathrm{Hg}$ at constant alveolar oxygen tension. The pulmonary diffusing surface did not measur- ably alter with exposure to an alveolar oxygen tension of $2,400 \mathrm{~mm} \mathrm{Hg}$ for 10 minutes before the measurement of $\mathrm{DL}_{\mathrm{CO}}$.

Control values at sea level of $\mathrm{DL}_{\mathrm{co}}$ and $\dot{\mathrm{Q}} \mathrm{c}$ were done before and after the above studies. An average $14 \%$ decrease in $\mathrm{DL}_{\mathrm{Co}}$ was found accompanied by a drop in Qc. These changes were thought to result from the subjects' prolonged inactivity in the chamber during decompression rather than to be due to oxygen inhalation or to increased barometric pressure per se.

\section{Acknowledgments}

The authors wish to express their appreciation to Mrs. Mary Friedmann, Mr. Denis Umidi, and Mr. George Kriebel for their assistance.

\section{References}

1. Ogilvie, C. M., R. E. Forster, W. S. Blakemore, and J. W. Morton. A standardized breath holding technique for the clinical measurement of the diffusing capacity of the lung for carbon monoxide. J. clin. Invest. $1957,36,1$.

2. Forster, R. E., F. J. W. Roughton, L. Cander, W. A. Briscoe, and F. Kreuzer. Apparent pulmonary diffusing capacity for $\mathrm{CO}$ at varying alveolar $\mathrm{O}_{2}$ tensions. J. appl. Physiol. 1957, 11, 277.

3. Haldane, J. S. Respiration. New Haven, Yale University Press, 1922 , p. 362.

4. Cander, L., and R. E. Forster. Determination of pulmonary parenchymal tissue volume and pulmonary capillary blood flow in man. J. appl. Physiol. 1959, $14,541$.

5. Johnson, R. L., Jr., W. S. Spicer, J. M. Bishop, and R. E. Forster. Pulmonary capillary blood volume, flow and diffusing capacity during exercise. J. appl. Physiol. 1960, 15, 893.

6. Lawson, W. H., Jr., H. N. Duke, R. W. Hyde, and R. E. Forster. Relation of pulmonary arterial and venous pressure to diffusing capacity. J. appl. Physiol. 1964, 19, 381. 
7. Bates, D. V., and R. V. Christie. Intrapulmonary mixing of helium in health and emphysema. Clin. Sci. 1950, 9, 17.

8. Forster, R. E., W. S. Fowler, D. V. Bates, and B. Van Lingen. The absorption of carbon monoxide by the lungs during breathholding. J. clin. Invest. 1954, 33, 1135.

9. McNeill, R. S., J. Rankin, and R. E. Forster. The diffusing capacity of the pulmonary membrane and the pulmonary capillary blood volume in cardiopulmonary disease. Clin. Sci. 1958, 17, 465.

10. Comroe, J. H., Jr., R. E. Forster, A. B. DuBois, W. A. Briscoe, and H. Carlsen. The Lung. Chicago, Year Book, 1955.

11. Forster, R. E. Exchange of gases between alveolar air and pulmonary capillary blood : pulmonary diffusing capacity. Physiol. Rev. 1957, 37, 391.

12. Comroe, J. H., Jr., R. D. Dripps, P. R. Dumke, and M. Deming. Oxygen toxicity; the effect of inhalation of high concentrations of oxygen for twenty-four hours on normal men at sea level and at simulated altitude of 18,000 feet. J. Amer. med. Ass. 1945, 128, 710.

13. Ernsting, J. The effect of breathing high concentrations of oxygen upon the diffusing capacity of the lung in man. J. Physiol. (Lond.) 1961, 155, 51P.

14. F. J. W. Roughton, and R. E. Forster. Relative importance of diffusion and chemical reaction rates in determining rate of exchange of gases in the human lung, with special reference to true diffusing capacity of pulmonary membrane and volume of blood in the lung capillaries. J. appl. Physiol. 1957, 11, 290.

15. Young, W. A., D. B. Shaw, and D. V. Bates. Effect of low concentrations of ozone on pulmonary function in man. J. appl. Physiol. 1964, 19, 765.

16. Lambertsen, C. J., S. G. Owen, H. Wendel, M. W. Stroud, A. A. Lurie, W. Lochner, and G. F. Clark.
Respiratory and cerebral circulatory control during exercise at .21 and 2.0 atmospheres inspired $\mathrm{pO}_{2}$. J. appl. Physiol. 1959, 14, 966.

17. Lambertsen, C. J., R. H. Krough, D. V. Cooper, G. L. Emmel, H. H. Loeschcke, and C. F. Schmidt. Comparison of relationship of respiratory minute volume to $\mathrm{pCO}_{2}$ and $\mathrm{pH}$ of arterial and internal jugular blood in normal man during hyperventilation produced by low concentrations of $\mathrm{CO}_{2}$ at 1 atmosphere and by $\mathrm{O}_{2}$ at 3.0 atmospheres. J. appl. Physiol. 1953, 5, 803.

18. Lambertsen, C. J., J. H. Ewing, R. H. Kough, R. Gould, and M. W. Stroud, 3rd. Oxygen toxicity. Arterial and internal jugular blood gas composition in man during inhalation of air, $100 \% \mathrm{O}$, and $2 \% \mathrm{CO}_{2}$ in $\mathrm{O}_{2}$ at 3.5 atmospheres ambient pressure. J. appl. Physiol. 1955, 8, 255.

19. Rennie, D. W., and J. R. Pappenheimer. Arterial oxygen pressure in dogs breathing oxygen at 2.5 atmospheres pressure. Proc. Soc. exp. Biol. (N. Y.) $1958,99,515$.

20. Saltzman, Herbert. Circulation, in press.

21. Staub, N. C., J. M. Bishop, and R. E. Forster. Importance of diffusion and chemical reaction rates in $\mathrm{O}_{2}$ uptake in the lung. J. appl. Physiol. 1962, 17, 21.

22. Fenn, W. O., and H. Rahn, section eds. Respiration, Handbook of Physiology. Washington, D. C., American Physiological Society, 1964, section 3, vol. 1, p. 845 .

23. Staub, N. C. Alveolar-arterial oxygen tension gradient due to diffusion. J. appl. Physiol. 1962, 18, 673.

24. Hyde, R. W., and R. E. Forster. Determination of the pulmonary diffusing capacity for $\mathrm{O}_{2}\left(\mathrm{DL}_{2}\right)$ by a breathholding technique. Physiologist 1963, 6, 206.

\section{SPECIAL NOTICE TO SUBSCRIBERS}

Post Offices will no longer forward the Journal when you move.

Please notify The Journal of Clinical Investigation, Business Office, 10 Stoughton Street, Boston, Mass. 02118, at once when you have a change of address, and do not omit the Zip Code number. 